\title{
IS THE USE OF FINANCIAL ACCOUNTING FIT FOR PURPOSE? AN EXPLORATION OF THE THEORETICAL FOUNDATIONS, FRAMEWORK AND PRACTICALITIES
}

\begin{abstract}
Purpose: The aim of this paper is to explore issues in related to the use of financial accounting and reporting by discussing three interrelated areas: (i) the theoretical foundations, (ii) the framework and (iii) practicalities. The paper also discusses participatory and pluralistic approaches to accounting and corporate governance as alternatives to address some of these issues.

Design/Methodology/Approach: This is narrative research based on deductive thematic analysis of secondary data. This study provides a general overview of the existing literature of the limits of the use of financial accounting and its impact on business and society.

Findings: In terms of the theoretical foundations, this paper contrasts financial accounting explained by agency theory and a dialogic accounting approach. The findings of this study emphasize the need to establish an accounting framework for the interests of the many (not the few) in conjunction and simultaneously with a participatory and pluralistic approach to corporate governance. Finally, this paper explores accounting for carbon emissions and recent financial accounting scandals to analyse the impact of the inappropriate use of financial accounting and reporting in business and society.

Originality: This paper provides an overview of the limits of the use of financial accounting by exploring its theoretical background, framework and practicalities. The paper also discusses the need for new accounting and corporate governance frameworks that allow for a pluralistic and participatory approach to the decision making of companies.
\end{abstract}

Keywords: Financial accounting, dialogic accounting, engagement and corporate governance. 


\section{Introduction}

This paper explores the limited function of financial accounting to sustain corporate practices fit for decision making in the context of the global finance economy. Financial accounting is a tool for financial decision making at the corporate level; therefore, it cannot be considered as an isolated set of numbers, but rather it should be consider as part of a much larger context. Financial accounting helps capitalism to organise freedom in the market and to provide rational explanations for capital accumulation on the basis of liberal economic democracy (Alawattage and Wickramasinghe, 2019). This is because competitive markets work efficiently via supply and demand establishing equilibriums. However, at the micro level of a corporation, mechanisms need to be in place to secure the 'efficient' use of financial capital since the origins of corporations mark a clear separation between the owners of capital and managers. Thus, financial accounting is a legalized visual and calculative language that organises the monetary performance of corporations to justify capital accumulation (Alawattage and Wickramasinghe, 2019).

The literature mentions that one of the most serious issues of financial accounting is that it is sustained by neoclassical economics assumptions (Tinker et al., 1982; Tinker, 1984). This prevents, for example, financial accounting from representing reality fairly because financial accounting uses economic reductionism to express quantitative measurements of organisational performance (Tinker et al., 1982; Tinker, 1984). In addition, financial accounting constructs boundaries to organisations based on an arbitrary set of standards that are implemented via a process of classification and measurement (Davis et al., 1982; Hines, 1988). This process of measurement, classification and control aims to maximize individual utility, and thus it inhibits the inclusion of externalities, causing pervasive impacts on the natural environment and society (Dierker and Preston, 1977; Gray et al., 1988).

This paper offers three complementary contributions to the above literature. First, this paper contrasts theoretical frameworks to expand the usefulness of accounting and corporate reporting. This discussion is driven by the necessity to generate broader organisational engagement via a dialogical approach (Brown and Dillard, 
2013; Mouffe, 2013; Bebbington et al., 2007; Brown, 2009) to incorporate a range of aspects rather than a pure emphasis on economic performance. Second, this paper critically analyses financial accounting conventions as a mechanism to build organisational barriers with the views of capital accumulation. This is relevant because organisations need to be aware of risks and uncertainties, which can only be identified using an inclusive range of information sources that extrapolates the boundaries of financial accounting and reporting (Bebbington and LarrinagaGonzalez, 2008). Third, the paper provides a reflection based on real-life examples, showing the pervasive impacts of the unfit use of financial accounting for business and society and its limitations as a financial decision making mechanism that determines resource allocation.

The remainder of this paper is organised as follows. The second section explores the theoretical foundations of financial accounting in which agency theory is contrasted with the dialogical approach. The third section explains the research methods and methodology. The fourth section provides a critical reflection of the financial accounting and reporting framework to support decision making on the efficient allocation of resources. The fifth section discusses the limitations of financial accounting and reporting in practical terms. The sixth section suggests a participatory approach to financial accounting and reporting. Finally, the fifth section provides final comments.

\section{Theoretical foundations of financial accounting and reporting}

\subsection{Economic approach}

There are different theoretical approaches to justify the existence of financial accounting. Agency theory, which uses an economic rationale, is one of the most used frameworks (Alawattage and Wickramasinghe, 2019; Solomon, 2013; Deegan, 2013; Gray et al., 2014). The foundation of agency theory is neoclassical economics, and utility maximization is at the core because neoclassical economics tries to solve the resource scarcity problem to satisfy human needs. More specifically, agency theory uses neoclassical assumptions to explain agency relationships that, according to Jensen and Meckling (1976), can be defined "as a contract under which one or 
more persons (the principal (s)) engage another person (the agent) to perform some service on their behalf which involves delegating some decision making authority to the agent" (p.308). In the context of agency theory, agents should have a single function, which is to maximize the principal's profits.

There are many questions that arise when financial accounting is explained using the lens of agency theory. However, this paper will concentrate on the following question: What is the boundary of a firm? For some economists, such as Ronald Coase, the boundary of a firm is limited to their contractual relations (Jensen and Meckling, 1976; Friedman, 1970). Authors from other theoretical perspectives defend that the boundary of a firm is much broader than contractual relations, and it involves firm relationships as a whole (Bebbington et al., 2007; Brown, 2009; Brown and Dillard, 2013, 2015a). Unfortunately, financial accounting and reporting adopts a limited perspective by supporting a reduced view of a business because it tends to concentrate on the financial transactions of a firm by communicating only its financial performance in a short period, reinforcing and legitimizing profit maximization and capital accumulation (Tinker, 1984; Hines, 1988).

\subsection{Dialogical approach}

The previous section discussed accounting using an economic perspective. This section critically explores accounting by referring to policy studies. More specifically, this section considers the pluralist approach (E.g.:Mouffe, 2013; Laclau and Mouffe, 2001), which has recently developed as the basis of agonistic political theory (Brown, 2017).

Agonistic political theory challenges the rationalism and individualism of liberalism because it will tend to achieve a rational consensus and reconciliation that supports powerful elites (Mouffe, 2013). Contrary to liberalism, agonistic political theory envisages antagonism, which is expressed by empowering conflictive views and struggles between adversaries - not enemies (Mouffe, 2013). A consensus is considered problematic and impossible to achieve. 
The participatory approach in accounting is justified by the fact that businesses involve citizenship issues, and thus the public should scrutinize its operations (Brown and Dillard, 2015a). This approach involves two interrelated processes that should aim to create value for stakeholders: (i) pluralistic and participatory governance and (ii) accounting that enables participatory governance through a reflection of organisational practices from different sociopolitical perspectives (Brown and Dillard, 2015a, 2015b; Bebbington et al., 2007). Participatory and pluralistic governance enables the engagement of different discourses and structures to review the accountability technologies in place. Plural participation is an alternative to challenge the status quo because it would require the inclusion of a broad range of perspectives, thus acknowledging and confronting asymmetries of power (Brown and Dillard, 2015a; Bebbington et al., 2007). Engagement is then essential because it has the potential to challenge current forms of governance structures run by dominated elites (Brown and Dillard, 2015a; Bebbington et al., 2007) and include marginalized groups (Bebbington et al., 2007).

Some authors suggested a transition from a monologic to a dialogic type of accounting (Bebbington et al., 2007; Brown, 2009; Brown and Dillard, 2013, 2015a). As table 1 shows, monologic accounting concentrates on a rational consensus, and it is discharged via mainstream accounting. Conventional accounting is based on facts and portrayed as neutral, and it uses technical language understood by experts. In the context of monologic accounting, profit maximization should be prioritized, and thus the dominance of capital markets and a shareholder focus are taken for granted. Governance is delegated to a minority elite. Conversely, dialogic accounting is confrontational in nature because it aims to create shareholder value, and thus it can take place in multiple spaces where conflicting perspectives emerge. Its format involves a variety of calculative and narrative formats to address different audiences. Finally, it contests the dominant discourse of profit maximization and refuses the privilege of capital markets, opening space for inclusion and a participatory type of governance.

[Insert Table 1 here] 
Despite the benefits of a participatory approach to accounting, its implementation remains a challenge. Many difficulties were identified in the literature. For example, the use of the technical language of conventional accounting is a barrier for many marginalized groups, and it is difficult to provide accountability using different formats from a variety of sociopolitical perspectives (Brown and Dillard, 2015a). Finally, there is a need to constantly challenge power asymmetries and dominant neoclassical assumptions, which prevents stakeholder engagement in an open dialogue (Brown and Dillard, 2015a).

\section{Research methods and methodology}

This paper is narrative research that explores the limits of financial accounting and reporting (Berg, 2004; Eriksson and Kovalainen, 2010). Secondary data from many sources are analysed, such as the following (see table 2): (i) the UK Conceptual Framework for Financial Reporting, (ii) the UK Corporate Governance Code, (iii) the annual reports produced by companies in the combustible sector with European Union Emissions Trading (EU ETS) inhalations, (iv) Financial Reporting Council reports on the investigation of financial scandals, (v) professional reports and webpages and (vi) newspaper articles. Deductive thematic analysis (Boyatzis, 1998; Joffe and Yardley, 2004) was applied to develop a narrative (Eriksson and Kovalainen, 2010) on the limits of the use of financial accounting and reporting applying the lens of a dialogical approach to accounting.

\section{Framework of financial accounting and reporting}

\subsection{Accounting as a mechanism of control and boundary setting}

This section will continue exploring the boundaries of organisations, but it will now emphasise how financial reporting can delineate such limits. According to the new UK Conceptual Framework for Financial Reporting (International Financial Reporting Standards - IFRS Foundation, 2018), the objective of financial reporting is described as follows: 
"The objective of general purpose financial reporting is to provide financial information about the reporting entity that is useful to existing and potential investors, lenders and other creditors in making decisions relating to providing resources to the entity. Those decisions involve decisions about:

(a) buying, selling or holding equity and debt instruments;

(b) providing or settling loans and other forms of credit; or

(c) exercising rights to vote on, or otherwise influence, management's actions that affect the use of the entity's economic resources." (p. A17)

This definition clarifies at least three main boundaries that are set by financial reporting. The first boundary refers to the concise audience of financial reporting, which is limited to those that provide financial resources to the organisation, such as the following: 'Investors, lenders and other creditors'. The second barrier is that financial reporting concentrates on financial information only. Finally, the third barrier is that financial reporting concentrates on the financial information of one particular entity in isolation. The neoclassical assumption of utility maximization at the micro level of a corporation is very clear in the above definition. All other information within one entity that is not financial is excluded. This is a rational choice to prioritize information on profit maximization.

The norms that regulate financial reporting are the following: accounting conventions, accounting standards and other sets of regulations (e.g., company law and norms set by stock markets and other national/international regulations) (Bebbington et al., 2001). An analysis of accounting conventions can provide a more detailed overview of the limits of financial reporting. Accountancy conventions are concepts generally accepted in the elaboration of external financial reporting (Financial Reporting Council - FRC, 2017). These concepts help to delineate boundaries of financial reporting, and thus these boundaries can also be perceived as limitations of financial reporting to embrace a pluralistic accounting approach. Table 3 below explains the accounting conventions.

In summation, table 3 reinforces that accounting conventions set the barriers for an organisation to use exclusively financial information within a short-term perspective. Thus, financial reporting is periodical financial information that can show whether 
the objectives of organisations (as a unit of a business) are in line with macroeconomic objectives of wealth accumulation. This is indeed a powerful rational and objective mechanism of governance that works at a distance to maintain the current notions of capitalism by emphasizing a consistent notion of capital exploitation and accumulation, which is portrayed as "the true and fair view" of organisational performance (Alawattage and Wickramasinghe, 2019).

\section{[Insert Table 3 here]}

According to the UK Conceptual Framework of Financial Reporting, financial information should also have qualitative characteristics, such as the following: relevance (including information relevant for decision making - the value of the information to users), materiality (including information that influences the decisions of the primary users of the information if omitted, misstated or obscured - nature or magnitude) and faithful representation (information should be complete and neutral with no bias and error-free) (International Financial Reporting Standards - IFRS Foundation, 2018). The materiality and relevance of financial information are also important topics to consider in terms of the pluralistic approach to accounting. These topics are explored in more detail using a practical example of emissions allowances in section 4.1 that follows.

It is relevant to clarify that this study does not dispute the fact that financial accounting works well to achieve the aims established in the framework. This paper also recognizes that the limitations of financial accounting and reporting are transparent in the framework. However, financial accounting is a tool that needs to be used by professionals to produce an outcome. Thus, the accountancy profession is institutionalized within an organized hierarchical structure of power, which dictates how the financial information of corporations should be managed, elaborated, presented and verified/audited (Alawattage and Wickramasinghe, 2019). This hierarchical structure comprises the following: regulators (e.g., the Financial Reporting Council), professional accounting bodies (e.g., ACCA, ICAEW, CIMA and ICAS) and accounting firms/professional accountants (e.g., KPMG, E\&Y, PwC and 
Deloitte) (Oxford Economics and CCAB, 2018; FRC, 2017). The accountancy profession is then normalized and regulated within this structure. Consequently, financial reporting is produced by accountancy professionals who participate in this structure and are instructed to follow standardized reporting norms (IFRS Foundation, 2018).

Many problems related to financial accounting and reporting are associated with its inappropriate use, so this paper seeks to highlight some of these problems. More specifically, this paper argues that a meaningful transformation of financial accounting and reporting is necessary. This transformation process should be conveyed simultaneously by both pluralistic and participatory governance and accounting that enables participatory governance.

The next section explores the need to change financial accounting and reporting to enable informed decision making and risk management.

\subsection{The use of financial reporting for decision making and risk management}

"The first version of the UK Corporate Governance Code (the Code) was published in 1992 by the Cadbury Committee. It defined corporate governance as 'the system by which companies are directed and controlled. Boards of directors are responsible for the governance of their companies. The shareholders' role in governance is to appoint the directors and the auditors and to satisfy themselves that an appropriate governance structure is in place.' This remains true today, but the environment in which companies, their shareholders and wider stakeholders operate continues to develop rapidly."(FRC, 2018c: 1)

The quote above refers to the definition of corporate governance in the new version of the UK Corporate Governance Code. This quote expresses that corporate governance is a system to control and direct companies. This quote also recognises that companies are inserted in a constant changing environment, and thus companies' operations cannot be assessed in isolation. Companies require investments, and thus the risks involved in business dynamics can lead to gains or losses (Solomon, 2013). Thus, correct incentives should be in place to identify, 
manage, mitigate and avoid high-risk strategies (Gendron et al., 2016). The Financial Reporting Council published guidance on risk management, internal control and related financial and business reporting (FRC, 2014). This guidance stresses the relevance of corporate disclosure to increase transparency on the risks and uncertainties faced by the business. It also reinforces the premise that risks are particular to each type of business, and thus disclosure should help users understand these peculiarities (FRC, 2014).

However, the previous sections of this paper explained that financial statements have a limited scope, and thus they provide a partial view of organisations' operations. Thus, concentrating decision making in only financial statements is insufficient. There were several mandatory initiatives in the UK to complement the scope of financial reporting. Table 4 shows examples of the compulsory social and environmental information in annual reports. These disclosure initiatives are welcomed, but they are still insufficient to provide comparability and a multidimensional perspective of the business in the long term.

The Operating Financial Review (OFR) was one relevant attempt in the UK to enable broader participation and engagement with financial reporting (Gray et al., 2014; Solomon, 2013). The proposal suggested a compulsory narrative analysis of the financial position of large companies in annual reports using plain language and including nonfinancial information (Gray et al., 2014; Solomon, 2013). For example, the OFR would require an account of companies' relationships with main stakeholders such as employees, customers and suppliers (Gray et al., 2014). In addition, the OFR would require disclosures on companies' policies and performance on environmental, community, social, ethical and reputational issues (Gray et al., 2014). This initiative failed, and consequently it was decided that nonfinancial disclosures in annual reports should comply with the EU Modernization Directive 2003(Gray et al., 2014; Solomon, 2013). 


\section{Practicalities: Is financial accounting sufficient to support informed decision making?}

\subsection{The case of emissions allowances}

In 2005, the EU ETS was launched as a policy to tackle climate change. The EU ETS set a cap on emissions per installation. Then, organisations can decide if they will reduce emissions or buy emissions in the market to compensate for their emissions over the established cap. Just before the EU ETS started to operate, in 2004, the IFRC issued IFRIC interpretation 3 on Emissions Rights. However, in June 2005, this interpretation was withdrawn due to potential volatility and mismatches.

\section{[Insert Table 4 here]}

There have not been accounting financial standards on emissions allowances since this attempt approximately 15 years ago. As a result, companies use a variety of accounting approaches to account for emissions rights, thereby impairing the comparability of financial statements (Black, 2013; Cook, 2009; Deloitte, 2012; Lovell et al., 2013; PWC and IETA, 2007). Several attempts were made to establish an alternative to this predicament, including a joint initiative by the Financial Accounting Standards Board (FASB) and the International Accounting Standards Board (IASB), but they were unsuccessful. A recent development on this issue is research on emissions allowances on hold at the IASB under the title "the Pollutant Pricing Mechanisms project" (https://www.iasplus.com/enca/projects/ifrs/research-projects/pollutant-pricing-mechanisms-formerlyemissions-trading-schemes).

Emissions markets are growing around the world, and they set a price for pollution/emissions; therefore, it is expected that these financial events would be recognised in financial statements, considering that emissions are relevant and material to the users of accounting (Lovell et al., 2013). According to the World Bank Group, there are currently 26 carbon markets operating around the world. Market initiatives, such as carbon markets and carbon taxes, accounted for $20 \%$ of the global greenhouse gases, representing US\$82 billion in 2018 (World Bank Group, 2018, 
2019). Despite these figures, the literature shows a high incidence of nondisclosure of carbon allowances in financial statements (Lovell et al., 2013; PWC and IETA, 2007).

Very few participants in the EU ETS provided information in financial statements that allows one to trace reductions in the use of emissions allowances per year. Only four out of $16^{i}$ combustible companies with EU ETS installations listed by Lovel et al. (2013) provided such data (see table 5). Moreover, only three of these 16 firms disclosed results on sales of carbon allowances (Eesti Energia, CEZ and Vattenfall Nederland B.V.- formerly Nuon). Standard setters may find it difficult to find a reason to account for carbon emissions if there is no material profit to disclose since profits are one of the most relevant measures of success in financial accounting.

\section{[Insert Table 5 here]}

Many studies have explored emissions allowances to highlight examples of the limitations of financial reporting standards. For example, MacKenzie (2009) mentioned that carbon markets are an economic mechanism that gives a price to an externality, and accounting is unable to translate this 'economic reality' into financial standards. Lovell et al. (2013) mentioned that financial reporting creates a reality because accounting is a tool from which many financial decisions are made. Thus, if emission allowances are not disclosed, relevant information is omitted, thus affecting not only users' decision making, but also the reputation of the accounting profession regarding its commitment to tackle climate change. Finally, the lack of engagement of standard setters was also highlighted as a barrier to understanding interdisciplinary issues, such as climate change (de Aguiar, 2018; Lovell, 2014; Lovell and MacKenzie, 2011; Thistlethwaite, 2011).

The next section complements the above discussion by providing real-life examples that illustrate the negative impact that an unfit use of financial accounting may have on businesses and broader society. 


\subsection{A reflection on financial scandals}

Effective corporate governance should implement mechanisms to control the operations of organisations and mechanisms to verify the accuracy of financial information (Solomon, 2013). Examples of control mechanisms include the following: nonexecutive directors on the board of directors, internal and external auditing and the existence of internal committees in areas of auditing, remuneration and nominations (Solomon, 2013). However, financial scandals are continuously occurring even when these control mechanisms are in place. Table 6 gives examples of such scandals. Please note that these scandals are only extreme examples. The Financial Reporting Council is investigating other cases that can be found at the following: https://www.frc.org.uk/auditors/enforcement-division/current-casesaccountancy-scheme.

Much has been discussed on potential ways to prevent these faults. One relevant issue discussed is executive remuneration (Solomon, 2013; KPMG, 2018). A recent commissioned report recommended some mechanisms to control executive remuneration in order to prevent abuses and the manipulation of financial reports, which is a reference for performance measurement that can consequently influence variable remuneration. Examples of those measures are the following: the disclosure of executive remuneration contracts, the disclosure of the names and ethnicities of employees who earn over $£ 150,000$ per year and the disclosure of a clear justification for bonuses attached to extraordinary performance (Sikka et al., 2018).

Another aspect under scrutiny is the independence of auditors and their participation in the market (Solomon, 2013). For example, in $2018,93 \%$ of the FTSE 100 was audited by the Big 4s (KPMG, E\&Y, PwC and Deloitte, (FRC, 2019). The control of the external auditing market by very few firms can potentially affect the independence of the services provided due to potential conflicts of interest (Work and Pensions and BEIS, 2018). In addition, the fact that auditing firms normally offer other consulting services to existing audit clients has also been under scrutiny (FRC, 2018b; Work and Pensions and BEIS, 2018). Recently, the Competition and Markets Authority (CMA) opened a review of accountancy firms in response to lost 
confidence in assurance services due to the considerable number of recent scandals (ICAEW, 2019b). Auditing firms are acting in response to this review. For example, KPMG committed to eliminate nonauditing services to FTSE 350 audit clients (ICAEW, 2018a). However, these actions were not sufficient to restore confidence in financial information, and the CMA and politicians are pressuring authorities to separate the big audit firms in order to secure the quality of the services provided (ICAEW, 2019b; Work and Pensions and BEIS, 2018; ICAEW, 2019a).

There is also an active debate on the role of auditing in a participatory governance approach. For example, there are suggestions that auditors should act as whistle blowers on illegal practicesii. In addition, an independent review of the quality and effectiveness of audits conducted by Sir Donald Brydon emphasized a broader scope of auditing (Brydon, 2019a) Recommendations from this review included the following (Brydon, 2019b): (i) auditors should be free to disclose original and material information to a wide range of users and not only shareholders; (ii) standards and rules should be set to govern the behaviour of corporate auditors; (iii) there should be education, training and retraining of professionals involved with corporate auditing, including forensic accounting and fraud; (iv) a simple mechanism should be established that enables the workforce to raise issues about risk and assurance; (v) audit fees should be disclosed; (vi) auditors should report significant risks similar to or greater than those reported by the directors; and (vii) auditors should report any disconnection between the culture companies claim via their directors and the behaviour observed by the auditors.

Table 6 also shows the impacts of financial scandals on different groups of individuals. This reinforces the need for a pluralistic account in order to consider how individuals are connected to organisations and how organisations are responsible for these links. Pluralistic and participatory accounting and governance suggests an approach that holds organisations accountable for marginalised groups that financial accounting and reporting normally ignores, as exemplified in table 6. Discussions on improvements in the use of accounting and governance stress the relevance of employee participation on the board of directors ${ }^{\text {iii }}$. The relevance of such 
participation lies in the fact that capitalism has been considered to be an extension of proprietarianism that defends private property (Piketty, 2020). In capitalism, the decision power is concentrated in the hands of the owners of the capital who control corporations based on their voting rights, which are assigned according to their shareholdings (Piketty, 2020). Thus, sharing power in corporations is one alternative that is suggested to overcome capitalism and private property, which would allow participatory decisions while allocating resources (Piketty, 2020).

\section{[Insert Table 6 here]}

In Germany, for example, since the late 1940s, workers have occupied half of the seats on boards of directors (Piketty, 2020). This decision was influenced by the postWorld War II movement when the German constitution established the definition of ownership rights, which included a broader perspective considering 'the general interest and the good of the community' (Piketty, 2020: 973). Comanagement in Germany has been successful in many aspects, for example, by setting long-term strategies and promoting more productive and equal models of work (Piketty, 2020).

The recent UK Corporate Governance Code shows an initial move towards broader engagement. For example, companies are now required to disclose their engagement with suppliers, customers and employees (FRC, 2018c). The UK Corporate Governance Code also requires half of the boards of directors to be nonexecutive directors (FRC, 2018c). However, compliance with the code is subject to a 'comply or explain' approach; therefore, questions can be raised on the effectiveness and urgency of the code at promoting engagement.

\section{Suggested participatory approach to financial accounting and reporting}

This section summarises the literature discussed above to suggest improvements to financial accounting and reporting towards a more participatory approach. First, this paper reinforces the idea that in order to improve accountability, it is essential to maintain good corporate governance practices. In turn, good corporate governance practices are essential to secure an appropriate use of financial accounting. Thus, 
participatory governance and accountability should coexist simultaneously (Brown and Dillard, 2015a, 2015b; Bebbington et al., 2007).

Second, in terms of financial reporting, this study suggests a similar approach to the Operating Financial Review in which large companies would provide an analysis of the financial position of their organisation. This analysis would be delivered in the format of a narrative using a plain language as part of the annual report. This analysis should also include an account of stakeholders' relationships and environmental, community, societal, ethical and reputational issues. This information would be open to consultation among employees before being published. Employees would have an opportunity to discuss the information and to raise concerns. A whistleblowing system would also be in place ${ }^{\text {iv }}$.

Standard setters could also support a participatory approach to financial accounting and reporting by engaging more broadly with accounting users and across disciplines (de Aguiar, 2018; Lovell, 2014; Lovell and MacKenzie, 2011; Thistlethwaite, 2011). This would help to understand new realities outside the scope of financial accounting, such as carbon markets. Finally, accountancy bodies should also enhance engagement with practitioners, academics and society to disseminate the role of accountants in tackling social and environmental problems currently faced. This could happen, for example, via social mediav and by sponsoring research on the area $^{\mathrm{vi}}$.

Third, in terms of governance, this paper suggests that the remuneration of directors, which vary according to firms' financial results, should be terminated. Fixed remuneration of more than $£ 150,000$ per year should be publicly disclosed (Sikka et al., 2018). Employees should be part of the boards of directors (Piketty, 2020). Finally, with regard to auditing, the recommendations from Sir Donald Brydon's review should be implemented. 


\section{Final comments}

This paper contributed to the literature by discussing the limits of the use of financial accounting and reporting by exploring three complementary issues: the theoretical foundations, the framework and practicalities. The discussions were initiated with a critical analysis of neoclassical economics as the frame to support concepts of financial accounting and reporting. It reinforced the need for a transition to a democratic approach to accounting that goes beyond corporate rational decisions of profit maximization at the cost of marginalised groups in society.

This paper also stressed the relevance of the dialogical approach to accounting and reporting as a possible alternative (Brown and Dillard, 2013; Mouffe, 2013; Bebbington et al., 2007; Brown, 2009). This is because financial accounting and reporting is a legalised and institutionalised set of hierarchical arrangements for supporting decision making from the perspective of an individual organisation and within the short term. Many regulatory requirements have been implemented to overcome these limitations. However, apparently, it is not a common interest to start a "revolution" in corporate reporting, but rather the focus is on a simple evolution to the current methods of business communication (PwC, 2019).

Finally, this paper argued on the usefulness of financial accounting and reporting by highlighting how its unfit use and limitations may have negative impacts on business and society. The current international finance economy context evokes a type of information and corporate governance that extends the financial boundaries of organisations and short-termism to evaluate the risks and uncertainties of business operations in a participatory and pluralistic manner. Thus, participatory and pluralistic accounting and governance should occur simultaneously. Reporting should then be perceived at the centre of this engagement process so that the ways in which financial accounting is currently produced and used may not be fit for this particular purpose. The paper also discusses some suggestions to improve the limitations to financial accounting and reporting, which may be of the interest to accounting professionals and policy makers. 
Future research on this topic can evaluate the impact of changes in the 2018 UK Corporate Governance Code to improve the use of financial accounting and engagement during decision making in UK companies. This research can specifically explore the views of employees in the process of improving corporate governance by highlighting the advantages and disadvantages of a more participatory process in the UK context. 
TABLES

Table 1 - Monologic $x$ dialogic accounting

\begin{tabular}{|c|c|c|}
\hline & DIALOGIC ACCOUNTING & MONOLOGIC ACCOUNTING \\
\hline FORMAT & $\begin{array}{l}\text { Variety of calculative and } \\
\text { narrative accountability. }\end{array}$ & Conventional accounting. \\
\hline $\begin{array}{l}\text { NATURE OF } \\
\text { INFORMATION }\end{array}$ & $\begin{array}{l}\text { - Confrontational in nature; } \\
\text { - Dominant discourse is } \\
\text { contested by including a } \\
\text { pluralistic perspective; } \\
\text { - Refuse to privilege capital } \\
\text { markets. }\end{array}$ & $\begin{array}{l}\text { - Based on consensus; } \\
\text { - Neutral scope based on facts to } \\
\text { support current status-quo; } \\
\text { - Rational and supportive of } \\
\text { utility maximization. }\end{array}$ \\
\hline PLATFORM & $\begin{array}{l}\text { - Developed in multiple spaces } \\
\text { where social conflicting } \\
\text { perspectives emerges; } \\
\text { - View from the outside of an } \\
\text { organisation. }\end{array}$ & $\begin{array}{l}\text { - Driven by normative forces } \\
\text { (e.g. regulations, standard } \\
\text { setters and professional } \\
\text { bodies); } \\
\text { - View from the inside of an } \\
\text { organisation. }\end{array}$ \\
\hline INCLUSION & Fully inclusive. & Shareholder focus. \\
\hline GOVERNANCE & Pluralistic and participatory. & Centred on minority elites. \\
\hline
\end{tabular}

Sources: Bebbington et al., 2007; Brown, 2009; Brown and Dillard, 2013, 2015a. 
Table 2-Secondary data

\begin{tabular}{|c|c|c|c|}
\hline $\mathbf{N}$ & Institution & Type & Description \\
\hline 1 & FRC & Staff Guidance Note & The Companies Act 2006 (Strategic Report and Directors' Report) Regulations 2013 - Key Facts (2013) \\
\hline 2 & FRC & Guidance & Guidance on risk management, internal control and related financial and business reporting (2014) \\
\hline 3 & FRC & Report & Non-financial reporting (2016) \\
\hline 4 & FRC & Report & Key facts and trends in the accountancy professions (2017) \\
\hline 5 & FRC & Report & BHS-Financial Reporting Council (2018) \\
\hline 6 & FRC & Report & Key facts and trends in the accountancy professions (2018) \\
\hline 7 & FRC & Report & The UK corporate governance code (2018) \\
\hline 8 & FRC & Report & Use of IFRC around the world (2018) \\
\hline 9 & ICAEW & News & SFO opens Tesco criminal investigation (2014) \\
\hline 10 & ICAEW & News & FRC closes probe into PwC's audit of Tesco (2017) \\
\hline 11 & ICAEW & News & KPMG to stop doing non-audit work on FTSE 350 clients (2018) \\
\hline 12 & ICAEW & news & Patisserie Valerie investigates potential accounting fraud (2018 \\
\hline 13 & ICAEW & News & BDO considers UK audit practice split (2019) \\
\hline 14 & ICAEW & News & CMA proposes radical reshaping of UK audit (2019) \\
\hline 15 & IFRC & News & Strengthening the relevance of financial reporting (2019) \\
\hline 16 & IFRC Foundation & Framework & Conceptual Framework for Financial Reporting (2018) \\
\hline 17 & KPMG & Report & Guide to directors' remuneration 2018 \\
\hline 18 & PwC & Report & The non-financial reporting regulations What do they mean in practice? (2017) \\
\hline 19 & PwC & Report & $\begin{array}{l}\text { The reporting dilemma - balancing the needs of shareholders and other stakeholders PwC's Annual Review of } \\
\text { Corporate Reporting in the FTSE } 350 \text { 2018/19 (2019) }\end{array}$ \\
\hline 20 & PWC and IETA & Report & Trouble-Entry Accounting: Revisited (2017) \\
\hline 21 & Labour policy making & Report & Controlling Executive Remuneration: Securing Fairer Distribution of Income (2018) \\
\hline 22 & BIES & Report & Report on Carillion: Conclusions and recommendation (2018) \\
\hline 23 & World Bank Group & Report & State and Trends of Carbon Pricing 2018 and 2019 \\
\hline 24 & Annual reports & Financial statements & Reports from combustion companies with EU ETS installations ETS listed in Lovell et al. (2013) \\
\hline 25 & Deloitte & Report & The carbon price accounting for carbon (2012) \\
\hline 26 & European Union & Guidelines & Guidelines on reporting climate-related information (2019) \\
\hline 27 & UK Government & Review & Independent Review and recommendations into the Quality and Effectiveness of Audit (2019) \\
\hline 28 & Newspaper articles & & A range of 12 articles published from 2014 to 2019 on audit fails in financial accounting scandals \\
\hline
\end{tabular}


Table 3-Accounting conventions

\begin{tabular}{|c|c|c|}
\hline CONVENTION & MEANING & $\begin{array}{c}\text { LIMITATION TO PLURALISTIC } \\
\text { APPROACH }\end{array}$ \\
\hline $\begin{array}{l}\text { Money } \\
\text { measurement }\end{array}$ & $\begin{array}{l}\text { Conventional accounting } \\
\text { concentrates on events } \\
\text { with monetary value } \\
\text { only. }\end{array}$ & $\begin{array}{l}\text { It prevents the inclusion of relevant } \\
\text { events which are not monetarily } \\
\text { measured, such as: Human rights, } \\
\text { environmental degradation, equality } \\
\text { and diversity, etc. }\end{array}$ \\
\hline Entity & $\begin{array}{l}\text { Financial reporting treats } \\
\text { an organisation and } \\
\text { participants of this } \\
\text { organisation separately. }\end{array}$ & $\begin{array}{l}\text { It emphasizes the notion that an } \\
\text { entity has to be perceived in } \\
\text { isolation as a profit maximization } \\
\text { unit. }\end{array}$ \\
\hline Going concern & $\begin{array}{l}\text { It is the assumption that } \\
\text { organisations will } \\
\text { continue its operation in } \\
\text { the future in its present } \\
\text { form. }\end{array}$ & $\begin{array}{l}\text { It can overestimate companies' } \\
\text { values. Future operations can be } \\
\text { committed by different reasons, such } \\
\text { as: bankruptcy, scarcity of resources } \\
\text { (e.g. oil exploitation), etc. Thus, going } \\
\text { concern provide support } \\
\text { misinterpretations of information. } \\
\text { Perhaps, a prudent perspective } \\
\text { would evaluate companies as if they } \\
\text { would fail by considering social and } \\
\text { environmental constrains rather than } \\
\text { take for granted their continuation. }\end{array}$ \\
\hline $\begin{array}{l}\text { Accrual and } \\
\text { matching }\end{array}$ & $\begin{array}{l}\text { Financial attributes of } \\
\text { events are recorded in } \\
\text { the period they occur. }\end{array}$ & $\begin{array}{l}\text { It can prevent a broader perspective } \\
\text { of events rather than only financial } \\
\text { focus; which benefits can be } \\
\text { perceived in a long distant future } \\
\text { when the institution may no longer } \\
\text { exist (e.g. emissions reductions). }\end{array}$ \\
\hline Prudence & $\begin{array}{l}\text { Caution and pessimism } \\
\text { while recording financial } \\
\text { events. }\end{array}$ & $\begin{array}{l}\text { It considers prudence in a narrow } \\
\text { view. Prudence should be expanded } \\
\text { to non-financial events. }\end{array}$ \\
\hline Consistency & $\begin{array}{l}\text { Financial report should } \\
\text { be produced on the } \\
\text { same basis every year } \\
\text { within the organisations. }\end{array}$ & $\begin{array}{l}\text { This shows that financial report } \\
\text { sustains the same status quo with no } \\
\text { conflicts and no changes. }\end{array}$ \\
\hline Periodicity & $\begin{array}{l}\text { Financial report should } \\
\text { be produced for a } \\
\text { specific period, which is } \\
\text { normally one year. }\end{array}$ & $\begin{array}{l}\text { This reinforces a short-term view of } \\
\text { profit maximization rather than long- } \\
\text { term perspective. }\end{array}$ \\
\hline
\end{tabular}

Source: Bebbington et al., 2001. 
Table 4: Examples of social and environmental disclosure in annual reports

\begin{tabular}{|c|c|}
\hline DISCLOSURE & CHARACTERISTICS \\
\hline $\begin{array}{l}\text { Business review } \\
\text { (UK Companies Act } \\
\text { 2006) }\end{array}$ & $\begin{array}{l}\text { Content: } \\
\text { A review of the business including, for example: Risks and } \\
\text { uncertainties as well as key performance indicators and non- } \\
\text { financial key performance indicators. } \\
\text { Note: } \\
\text { There is no clear guidance on social and environmental } \\
\text { disclosure. In addition, external auditing was not } \\
\text { compulsory but only encouraged. }\end{array}$ \\
\hline $\begin{array}{l}\text { Strategic report } \\
\text { (2013 Regulation) }\end{array}$ & $\begin{array}{l}\text { Content: } \\
\text { Strategic report should include all content of the Business } \\
\text { Review. For quoted companies, the regulation included } \\
\text { additional disclosure, such as: Strategy and business model } \\
\text { as well as human rights and gender diversity. } \\
\text { Note: } \\
\text { Strategic report is applied to all but not small companies. }\end{array}$ \\
\hline $\begin{array}{l}\text { Greenhouse gas } \\
\text { emissions disclosure } \\
\text { (2013 Regulation) }\end{array}$ & $\begin{array}{l}\text { Content: } \\
\text { Greenhouse gas emissions disclosure. } \\
\text { Note: } \\
\text { This information should be presented by quoted companies } \\
\text { in the Directors' Report. }\end{array}$ \\
\hline $\begin{array}{l}\text { Non-financial } \\
\text { information } \\
\text { (2016 Regulation - } \\
\text { response to the EU } \\
\text { Directive) }\end{array}$ & $\begin{array}{l}\text { Content: } \\
\text { Impact of businesses activity relating to: Environmental, } \\
\text { employee, social, respect for human rights, anti-corruption } \\
\text { and anti-bribery matters (FRC, 2016: :2). } \\
\text { Note: } \\
\text { This information should be presented in the strategic report } \\
\text { and it applies to large companies/groups. }\end{array}$ \\
\hline $\begin{array}{l}\text { Miscellaneous } \\
\text { reporting } \\
\text { (2018 UK Corporate } \\
\text { Governance Code) }\end{array}$ & $\begin{array}{l}\text { Content: } \\
\text { Examples of information required are: } \\
\text { - Engagement with supply chain, customers and employees; } \\
\text { - Corporate governance arrangements; } \\
\text { - CEO's remuneration in relation to employees; } \\
\text { - Impact of increasing in share price on directors' } \\
\text { remuneration. } \\
\text { Note: } \\
\text { This information expands the scope of the Strategic Report } \\
\text { and Directors' Report and it applies to companies only (e.g. } \\
\text { excludes Limited Liability Partnership). }\end{array}$ \\
\hline
\end{tabular}

Sources: FRC, 2018c; Solomon, 2013; FRC, 2016, 2013; PwC, 2017. 
Table 5: Examples of recent UK scandals related to financial reporting

\begin{tabular}{|l|l|r|r|}
\hline & $\begin{array}{c}\text { Company } \\
\text { name }\end{array}$ & $\begin{array}{c}\text { Emissions rights 2019 } \\
\text { (Million metric tons of CO2) }\end{array}$ & $\begin{array}{c}\text { Emissions rights 2018 } \\
\text { (Million metric tons of CO2) }\end{array}$ \\
\hline $\mathbf{1}$ & ENDESA & 31.1 & 34.8 \\
\hline $\mathbf{2}$ & EDF & 21 & 24 \\
\hline $\mathbf{3}$ & CEZ & 25,9 & 26,8 \\
\hline $\mathbf{4}$ & RWE & 81 & 118 \\
\hline
\end{tabular}

Source: 2019 financial statements of combustion companies with EU ETS installations listed in Lovell et al. (2013) 
Table 6: Examples of recent UK scandals related to financial reporting

\begin{tabular}{|c|c|c|c|c|c|c|}
\hline ORGANISATION & SECTOR & $\begin{array}{l}\text { YEAR OF } \\
\text { THE } \\
\text { SCANDAL }\end{array}$ & $\begin{array}{l}\text { RELATION TO FINANCIAL } \\
\text { REPORTING }\end{array}$ & $\begin{array}{l}\text { FINANCIAL } \\
\text { AMMOUNT } \\
\text { INVOLVED }\end{array}$ & $\begin{array}{c}\text { EXAMPLES OF } \\
\text { GROUPS AFFECTED }\end{array}$ & AUDIT FIRM \\
\hline Tesco & Supermarket & 2014 & $\begin{array}{l}\text { Overstated profits (e.g. paying } \\
\text { suppliers later and booking revenue } \\
\text { early). }\end{array}$ & $\begin{array}{l}\text { £263 million } \\
\text { overstatement in } \\
\text { two years. }\end{array}$ & $\begin{array}{l}\text { Suppliers and investors } \\
\text { (profit fallen - lower } \\
\text { dividends). }\end{array}$ & PwC \\
\hline BHS & $\begin{array}{l}\text { High Street } \\
\text { Retailer }\end{array}$ & 2016 & $\begin{array}{l}\text { Several allegations of misconduct, } \\
\text { such as manipulation of revenue, } \\
\text { cost of sales and operating } \\
\text { expenses using manual journal } \\
\text { entry via inter-group charge. }\end{array}$ & $\begin{array}{l}\text { Liquidation with a } \\
\text { pension scheme } \\
\text { deficit of } f 571 \\
\text { million }\end{array}$ & $\begin{array}{l}\text { 11,000 members of } \\
\text { staff lost their jobs and } \\
\text { pensions. }\end{array}$ & PwC \\
\hline Carillion & $\begin{array}{l}\text { Support } \\
\text { service } \\
\text { contractor }\end{array}$ & 2017 & $\begin{array}{l}\text { Accounts were constantly } \\
\text { manipulated to increase revenues. } \\
\text { Suppliers' payments were delayed } \\
120 \text { days. However, just before } \\
\text { carillion's collapse record dividends } \\
\text { were paid as well as large } \\
\text { performance bonus. }\end{array}$ & $\begin{array}{l}\text { - Liquidation with } \\
\text { liabilities of } \\
\text { approximately } \\
£ 7 \text { billion and } \\
£ 29 \text { million in } \\
\text { cash. } \\
\text { - } £ 2.6 \text { billion in } \\
\text { pension fund } \\
\text { liability }\end{array}$ & $\begin{array}{l}\text {-2,000 people lost } \\
\text { their jobs; } \\
\text { - } 27,000 \text { members of } \\
\text { pension fund } \\
\text { affected; } \\
\text { - Owed } £ 2 \text { billion to } \\
30,000 \text { to creditors; } \\
\text { - } £ 150 \text { million from } \\
\text { taxpayers. }\end{array}$ & $\begin{array}{l}\text { - KPMG } \\
\text { (external } \\
\text { auditor) } \\
\text { - Deloitte } \\
\text { (internal } \\
\text { auditor) } \\
\bullet \text { E\&Y } \\
\text { (turnaround } \\
\text { advisor) }\end{array}$ \\
\hline $\begin{array}{l}\text { Patisserie } \\
\text { Valerie }\end{array}$ & Café chain & 2018 & $\begin{array}{l}\text { Manipulated accounts with false } \\
\text { entries. For example, delay in } \\
\text { suppliers' payment to increase } \\
\text { profit and hold of cash was, } \\
\text { apparently, a common practice. }\end{array}$ & $\begin{array}{l}£ 20 \text { million debit } \\
\text { and } £ 1.14 \text { million } \\
\text { unpaid tax. }\end{array}$ & $\begin{array}{l}\text { Jobs losses and tax } \\
\text { payers' deficit. }\end{array}$ & $\begin{array}{c}\text { Grant } \\
\text { Thornton }\end{array}$ \\
\hline
\end{tabular}

Sources: FRC, 2018a; Work and Pensions and BEIS, 2018; ICAEW, 2017, 2014, 2018b. 


\section{REFERENCE LIST:}

Alawattage, C. and Wickramasinghe, D. (2019), Strategizing management accounting: Liberal origins and neoliberal trends. Routlege, London.

Bebbington, J., Brown, J., Frame, B., et al. (2007), "Theorizing engagement: the potential of a critical dialogic approach". Accounting, Auditing \& Accountability Journal Vol. 20 No. 3, pp. 356-381.

Bebbington, J., Gray, R. and Lauglhin, M.R. (2001), Financial Accounting: Practice and Principles (3rd Edition). Cengage, Andover.

Bebbington, J. and Larrinaga-Gonzalez, C. (2008), "Carbon trading: Accounting and reporting issues". European Accounting Review, Vol. 17, pp. 697-717.

Berg, B. (2004), Qualitative research methods. Ally and Bacon, Boston.

Black, C. (2013), "Accounting for carbon emission allowances in the European Union: In search of consistency". Accounting in Europe Vol. 10, pp. 223-239.

Boyatzis, R.E. (1998), Transforming qualitative information: Thematic analysis and code development paperback. SAGE, London.

Brown, J. (2009), "Democracy, sustainability and dialogic accounting technologies: Taking pluralism seriously". Critical Perspectives on Accounting Vol. 20, pp. 313342.

Brown, J. (2017), "Democratizing accounting: Reflections on the politics of "old" and "new" pluralisms". Critical Perspectives on Accounting Vol. 43, pp. 20-46.

Brown, J. and Dillard, J. (2013), "Agonizing over engagement: SEA and the "death of environmentalism" debates". Critical Perspectives on Accounting Vol. 24, pp. 1-18.

Brown, J. and Dillard, J. (2015a), "Dialogic accountings for stakeholders: On opening up and closing down participatory governance". Journal of Management Studies Vol. 52 No. 7.

Brown, J. and Dillard, J. (2015b), "Opening accounting to critical scrutiny: Towards dialogic accounting for policy analysis and democracy". Journal of Comparative Policy Analysis Vol. 17 No. 3, pp. 247-268.

Brydon, D. (2019a) Assess, assure and inform: Inproving audit quality and effectiveness. Report of the independent review into the quality and effectiveness of audit. London: Department for Business, Energy \& Industrial Strategy.

Brydon, D. (2019b) Independent review: List of recommendations. London: Department for Business, Energy \& Industrial Strategy.

Cook, A. (2009), "Emission rights: From costless activity to market operations". Organizations and Society Vol. 34, pp. 456-466.

Davis, S.W., Menon, K. and Morgan, G. (1982), "The images that have shaped accounting theory". Accounting, Organisations and Society Vol. 7 No. 4, pp. 307318.

de Aguiar, T. (2018), "Turning accounting for emissions rights inside out as well as upside down". Environment and Planning C: Politics and Space Vol. 36 No. 1, pp. 139-159.

Deegan, C. (2013), Financial Accounting Theory. MacGraw Hill Education, Melbourne. Deloitte (2012), "The carbon price accounting for carbon. Accessed on: 25.06.2019. Available at:

https://www.iasplus.com/en/publications/australia/other/accounting-forcarbon". 
Dierker, M. and Preston, L.E. (1977), "Corporate social accounting reporting for the physical environment: A critical review and implementation proposal".

Accounting, Organizations and Society Vol. 2 No. 3-22.

Eriksson, P. and Kovalainen, A. (2010), Qualitative mentods in business reaseach. Sage, London.

FRC (2013), "Staff Guidance Note: The Companies Act 2006 (Strategic Report and Directors' Report) Regulations 2013 - Key Facts. Accessed on 20.06.19. Available at: https://www.frc.org.uk/getattachment/4ed9ae52-64aa-4bf3-9990-

7f8d2b4d109b/FRC-Staff-Guidance-Note-\%E2\%80\%93-Strategic-ReportRegulations.pdf".

FRC (2014), "Guidance on risk management, internal control and related financial and business reporting. Accessed on 25.06.2019. Available at:

https://www.frc.org.uk/getattachment/d672c107-b1fb-4051-84b0f5b83a1b93f6/Guidance-on-Risk-Management-Internal-Control-and-RelatedReporting.pdf".

FRC (2016), "Non-financial reporting. Accessed on 20.06.19. Available at: https://www.frc.org.uk/getattachment/3dfe0ac6-ac6d-41a0-91bfdf98cbba0ad6/Non-Financial-Reporting-Factsheet-Final.pdf".

FRC (2017), "Key facts and trends in the accountancy professions. Accessed on 20.06.2019. Available at: https://www.frc.org.uk/getattachment/77fc8390-d0d14bfe-9938-8965ff72b1b2/Key-Facts-and-Trends-2017.pdf".

FRC (2018a), "BHS-Financial Reporting Council. Accessed on 25.06.2018. Available at: https://www.frc.org.uk/getattachment/433f3df8-d0ef-456b-8a26aeb55f65489b/BHS-Particulars-of-Fact-and-Acts-of-Misconduct.pdf".

FRC (2018b), "Key facts and trends in the accountancy professions. Accessed on 20.06.2019. Available at: https://www.frc.org.uk/getattachment/27725654-8bd94623-a410-ef1661a69649/Key-Facts-and-Trends-2018.pdf".

FRC (2018c), "The UK corporate governance code. Accessed on 20.06.19. Available at: https://www.frc.org.uk/getattachment/88bd8c45-50ea-4841-95b0d2f4f48069a2/2018-UK-Corporate-Governance-Code-FINAL.pdf".

FRC (2019), "Use of IFRC around the world. Accessed on 06.05.2020. Available at: https://www.frc.org.uk/getattachment/109373d4-abc2-424f-84d0b80c2cec861a/Key-Facts-and-Trends-2019.pdf".

Friedman, M. (1970), The social responsibility of business is to increase its profits, New York Times Magazine (Reprinted from Perspectives in business ethics, 3rd ed., pp. 280-285, by L. P. Hartman, Ed., 2005). McGraw-Hill, New York, NY.

Gendron, Y., Brivot, M. and Guénin-Paracini, H. (2016), "The construction of risk management credibility within corporate boardrooms". European Accounting Review, Vol. 25 No. 3, pp. 549-578.

Gray, R., Adams, C.A. and Owen, D. (2014), Accountability, Social Responsibility and Sustainability: Accounting for Society and the Environment. Pearson, Harlow.

Gray, R., Owen, D. and Maunders, K. (1988), "Corporate social reporting: emerging trends in accountability and the social contract". Accounting, Auditing \& Accountability Journal Vol. 1 No. 1, pp. 6-20.

Hines, R.D. (1988), "Financial accounting: In communicating reality, we construct reality". Accounting, Organisations and Society Vol. 13 No. 3, pp. 251-261. 
ICAEW (2014), "SFO opens Tesco criminal investigation. Accessed on: 25.06.2019. Available at: https://economia.icaew.com/en/news/october-2014/sfo-openstesco-criminal-investigation".

ICAEW (2017), "FRC closes probe into PwC's audit of Tesco. Accessed on: 25.06.2019. Available at: https://economia.icaew.com/news/june-2017/frc-closes-probe-intopwc-audit-of-tesco".

ICAEW (2018a), "KPMG to stop doing non-audit work on FTSE 350 clients. Accessed on: 25.06.2018. Available at: https://economia.icaew.com/news/november2018/kpmg-to-stop-doing-non-audit-work-on-ftse-350-clients".

ICAEW (2018b), "Patisserie Valerie investigates potential accounting fraud. Accessed on 25.06.2019. Available at: https://economia.icaew.com/news/october2018/patisserie-valerie-investigates-potential-accounting-fraud".

ICAEW (2019a), "BDO considers UK audit practice split. Accessed on: 25.06.2018. Available at: https://economia.icaew.com/news/april-2019/bdo-considers-ukaudit-practice-split".

ICAEW (2019b), "CMA proposes radical reshaping of UK audit. Accessed on 20.06.2019. Available at: https://economia.icaew.com/news/april-2019/cmaproposes-radical-reshaping-of-uk-audit".

IFRC (2019), "Strengthening the relevance of financial reporting. Available from: https://www.ifrs.org/news-and-events/2019/06/strengthening-the-relevance-offinancial-reporting/ [Accessed 25.06.2019]".

IFRS Foundation (2018), “Conceptual Framework for Financial Reporting. Available from: https://www.ifrs.org/projects/2018/conceptual-framework/ [Accessed on the 20.06.2019]".

Jensen, M.C. and Meckling, W.H. (1976), "Theory of the firm: Managerial behavior, agency costs and ownership structure.". Journal of Financial Economics Vol. 3 No. 4, pp. 305-360.

Joffe, H. and Yardley, L. (2004) Content and thematic analysis. In: Marks DF and Yardley $L$ (eds) Research methods for clinical and health psychology. London: SAGE.

KPMG (2018), “Guide to directors' remuneration 2018. Accessed on: 20.06.2018. Available at:

http://kpmg.co.uk.s3.amazonaws.com/creategraphics/2018/12 2018/CRT106973 LCRT106973 FTSE 350 SURVEY.pdf".

Laclau, E. and Mouffe, C. (2001), Hegemony and socialist strategy: Towards a radical democratic politics. Verso, London.

Lovell, H. (2014), "Climate change, markets and standards: the case of financial accounting,". Economy and Society Vol. 43 No. 2, pp. 260-284.

Lovell, H., Bebbington, J., Larrinaga, C., et al. (2013), "Putting carbon markets into practice: a case study of financial accounting in Europe". Environment and Planning C: Government and Policy Vol. 31 No. 4, pp. 741-757.

Lovell, H. and MacKenzie, D. (2011), "Accounting for carbon: The role of accounting professional organisations in governing climate change". Antipode Vol. 43, pp. 704-730.

MacKenzie, D. (2009), "Making things the same: Gases, emission rights and the politics of carbon markets". Accounting, Organizations and Society Vol. 34, pp. 440-455. 
Mouffe, C. (2013), Agonistics: Thinking the world politically. Verso, London.

Oxford Economics and CCAB (2018), "The accountancy profession in the UK. Accessed on 20.06.19. Available at:

https://www.ccab.org.uk/documents/20181122CCABEconomicreport2018Web.pd f".

Piketty, T. (2020), Capital and ideology. Harvard College Press, USA.

PwC (2017), "The non-financial reporting regulations What do they mean in practice? Accessed on 20.06.19. Available at: https://www.pwc.co.uk/auditassurance/assets/pdf/non-financial-reporting-regulations-2017.pdf".

PwC (2019), "The reporting dilemma - balancing the needs of shareholders and other stakeholders PwC's Annual Review of Corporate Reporting in the FTSE 350 2018/19. Accessed on 03.03.2020. Available at: https://www.pwc.co.uk/auditassurance/assets/pdf/ftse-350-corporate-reporting-2019.pdf ".

PWC and IETA (2007) Trouble-Entry Accounting: Revisited. London: PriceWaterhouse Coopers and the International Emissions Trading Association.

Sikka, P., Hadden, T., Christensen, J., et al. (2018), "Controlling Executive Remuneration: Securing Fairer Distribution of Income. Accessed on:24.06.2019. Available at: http://visar.csustan.edu/aaba/LabourExecutiveRemunerationReview2018.pdf". Solomon, J. (2013), Corporate Governance and Accountability. Willey, Cornwall.

Thistlethwaite, J. (2011), "Counting the environment: The environmental implications of international accounting standards". Global Environmental Politics Vol. 11, pp. 75-97.

Tinker, A.M. (1984), "Theories of the state and the state of accounting: Economic reductionism and political voluntarism in accounting regulation theory". Journal of Accounting and Public Policy Vol. 3, pp. 55-74.

Tinker, A.M., Merino, B.D. and Neimark, M.D. (1982), "The normative origins of positive theory ideology and accounting thought". Accounting, Organisations and Society Vol. 7 No. 2, pp. 167-200.

Work and Pensions and BEIS (2018), "Report on Carillion: Conclusions and recommendations. Accessed on 24.06.2019. Available at: https://www.parliament.uk/business/committees/committees-a-z/commonsselect/work-and-pensions-committee/news-parliament-2017/carillion-reportpublished-17-19/".

World Bank Group (2018), "State and Trends of Carbon Pricing 2018. Accessed on: 26.06.2019. Available at: https://openknowledge.worldbank.org/bitstream/handle/10986/29687/97814648 12927.pdf? sequence=5\&isAllowed $=\mathrm{y}^{\prime}$.

World Bank Group (2019), "State and Trends of Carbon Pricing 2019. Accessed on: 06.05.2020. Available https://openknowledge.worldbank.org/handle/10986/31755". 


\footnotetext{
'Three combustible companies listed at Lovel et al. (2013) were merged or acquired by other companies included the same list.

ii https://www.insider.co.uk/special-reports/fraud-big-four-what-should-21036208

iii https://leftfootforward.org/2017/08/heres-how-to-prevent-another-bhs-style-crisis/

iv Consultation with employees about corporate information is not a new practice. This was common practice in Brazil when companies produced Social Balance (https://ibase.br/userimages/BS 1.pdf). v https://www.deloitte.co.uk/climatechange/

vi https://www.accaglobal.com/pk/en/technical-activities/technical-resources-search.browse.stopic--Future of the profession Research report series.html
} 